\title{
Experience with Extra Hepatic Intra Abdominal Hydatid Cyst
}

\author{
Altaf Ahmed Talpur, ${ }^{1}$ Aijaz Ahmed Shaikh, ${ }^{1}$ Muhammad Imran Arain, ${ }^{2}$ Akmal Jamal Siddiqui' \\ 'Department of Surgery, Liaquat University of Medical and Health Sciences Jamshoro, Sind, Pakistan, ${ }^{2}$ Department of \\ Surgery, Liaquat University Hospital Hyderabad/ Jamshoro, Sind, Pakistan.
}

\section{ABSTRACT}

Introduction: Hydatid disease is a significant health problem with their location at Extrahepatic Intra abdominal sites is a very rare disease. Disease in these sites usually found concurrently with liver hydatid disease. Diagnosis is based blood tests \& imaging studies. Surgery is the mainstay of treatment. This study will help us in determining the frequency of Extra Hepatic Intra Abdominal Hydatid Disease. Also different methods to diagnose \& treat the disease will be evaluated.

Methods: It includes patients of extra hepatic intra abdominal Hydatid cyst above 13 years and underwent surgery from 2009 to 2014. Variables include age, sex, clinical findings, diagnostic investigations, operative findings, operative procedure, post operative complications.

Results: Eleven patients; 07 male \& 04 female; mean age 37.54 years. Most common symptoms were mass in abdomen in 11 patients \& dull pain abdomen in $09(81.8 \%)$ patients. Examination revealed non tender mass in epigastric \& umbilical region in $04(36.3 \%)$ patients. Ultrasound Abdomen showed hydatid cyst spleen in $02(18.1 \%)$ patients, epigastrium in $04(36.3 \%)$ patients, beneath left crus of diaphragm in $02(18.1 \%)$ patients \& right iliac fossa \& pelvis in $1(9.09 \%)$ patient. In 02 (18.1\%) patients multiple Hydatid cysts were noted. Hydatid cysts liver found in $07(63.6 \%)$ patients C.T scan Abdomen was performed in 09 (81.8\%) patients. Surgical procedures performed include Saucerization \& omental packing in liver Hydatid cysts; Splenectomy for Splenic disease \& complete excision of remaining intra-abdominal Hydatid cysts. Postoperative complications noted in 05 $(45.4 \%)$ patients.

Conclusion: Extra hepatic intra abdominal is an infrequent disease presents significant diagnostic \& therapeutic challenge for surgeons.

Keywords: extra hepatic; hydatid disease; intra abdominal.

\section{INTRODUCTION}

Hydatid disease is a significant health problem in many parts of the world with annual incidence of 18 to $20 / 100,000$ people. ${ }^{1,2}$ Liver is the commonest viscera involved followed by lung. ${ }^{3}$ Other areas rarely involved are peritoneal cavity, kidney, spleen, bone, retroperitoneum. ${ }^{4}$ Disease in these sites usually found concurrently with liver Hydatid disease. ${ }^{1,5}$ Diagnosis is based on Anti-echinococcal antigens \& antibodies. ${ }^{6}$ Ultrasound Abdomen typically demonstrates daughter cysts. CT Scan \& MRI are more helpful in delineating futher details related to diagnosis. ${ }^{7,8}$ Surgery is the mainstay of treatment. ${ }^{9}$

There is no data available in literature on extrahepatic Hydatid disease from this country despite having a sizeable number of Patients which produces significant

Correspondence: Dr. Altaf Ahmed Talpur, Surgical unit II Liaquat University of Medical \& Health Sciences, Jamshoro, Sindh Pakistan. Email: altafktalpur@yahoo.com, Phone: +923002185479. 
impact on the life \& health of the individual.

This study will help us in determining the frequency of Extra Hepatic Intra Abdominal Hydatid Disease. Also different methods to diagnose $\&$ treat the disease will be evaluated.

\section{METHODS}

This was a descriptive case series study conducted at public and private sector hospitals of Hyderabad, Pakistan from $1^{\text {st }}$ July, 2009 to $30^{\text {th }}$ June ,2014. All patients of either sex above the age of 13 years who were diagnosed as cases of extra hepatic Abdominal Hydatid cyst and underwent surgery were included in the study. Patients of extra hepatic Abdominal Hydatid cyst below the age of 13 years, not operated due to serious co morbid illness like Ischemic heart disease (ASA-3), severe chronic obstructive airway disease requiring ventilator support, and complicated chronic liver disease were excluded. Also patients who did not consented for study or lost to follow-up were excluded.

These patients were admitted in ward. Detailed history was taken especially in data related to age, sex, clinical presentation, co morbid illness, animal contact history, past history of same disease \& family history of Hydatid cyst. Thorough examination was performed with special focus on variables like anemia, jaundice, general health of the individual \& findings of swelling in abdominal examination. Investigations like complete blood count, blood sugar, blood urea and where required ECG and chest $\mathrm{x}$-ray were performed to assess general fitness. In addition investigations required to diagnose pathology like ultrasound of Abdomen, C.T scan of Abdomen \& Anti Echinococcus antibodies were performed to establish diagnosis. Diagnosis was made and patients were briefed about the diagnosis and procedure to be performed. Patients were informed and consent was granted. They were assured that their participation is voluntary with no harms to them in terms of getting due treatment. They were also given right to withdraw from study without putting any reasons. Permission for the study was granted from Head Department of Surgery in Public sector hospitals.

Preoperatively patients were put on antihelminth therapy (Albendazole $10 \mathrm{mg} / \mathrm{kg} / \mathrm{per}$ day in divided doses) for 30 days prior to surgery \& repeated the same drug postoperatively for 1 month. Laparotomy was performed under General anesthesia. Abdominal cavity opened. Green towels soaked in hypertonic saline were applied all around the swelling. In case of Hepatic Hydatid disease aspiration of fluid \& then instillation of hypertonic saline for $3-5$ minutes was performed before opening the cyst. Cyst opened \& all contents removed. Communication with the biliary tree ascertained \& if found it was closed with Vicryle. Cavity washed \& omentum applied in the cyst cavity after deroofing surface of the cyst (Saucerization). In case of Splenic Hydatid disease Splenectomy was performed. In patients with other intra-abdominal hydatid disease complete excision of cyst was performed. Drain was placed in sub hepatic space for Hepatic Hydatid cyst \& at the site of cyst excision in other cases. Postoperatively patients received I/V antibiotics. Patients were started orally once gut activity resumed. Drain was removed when less than $10 \mathrm{ml}$ discharge was coming in the drain. Patients were discharged when tolerated diet well, fully mobilized. Follow-up visits were advised at 10 days, $3,6 \& 12$ months to assess complications associated with the disease $\&$ procedure which includes recurrence of disease.

Data was collected on preformed proforma for variables including age, sex, clinical presentation, abdominal examination findings, diagnostic investigation findings; operative findings, operative procedure performed, any post-operative complications and hospital stay. Sampling strategy used in this study was non probability purposive method. Data were summarized using statistical package for social sciences version 16. Simple descriptive analysis was done for the calculation of number and percentage

\section{RESULTS}

During this five years period, 11 patients of extra hepatic intra Abdominal Hydatid cyst were evaluated. It includes 07 (63.6\%) male \& 04 (36.3\%) female patients. Mean age was 37.54 years (SD \pm 8.82 ) with minimum age was 28 years \& maximum age 51 years. Most common symptom was mass lesion in the abdomen which was found in all 11 patients. $09(81.8 \%)$ patients had dull pain in the abdomen with 04 (36.3\%) of them gave history of intermittent colic. History of jaundice \& Fever was present in 04(36.3\%) patients each. 08 $(72.7 \%)$ patients had history of weight loss \& nausea.

History of animal contact was present in all patients.

Past history of surgery for Hydatid liver disease was present in $07(63.6 \%)$ patients.

Examination findings revealed non tender, ill defined mass lesions of variable sizes in abdomen. These were present in epigastric \& umbilical region in 04 (36.3\%) patients, in left hypochondrium in $02(18.1 \%)$ patients $\&$ in right iliac fossa in $1(9.09 \%)$ patient. Multiple masses were noted at periumbilical areas \& at left hypochondrium in $02(18.1 \%)$ patients. Hepatomegaly was present in $06(54.5 \%)$ patients, splenomegaly in $02(18.1 \%)$ patients. 
Ultrasound Abdomen was performed in all patients. It showed hydatid cyst in spleen in $02(18.1 \%)$ patients, in lesser sac area anterior to pancreas in 04(36.3\%) patients, beneath left crus of diaphragm adjacent to left lobe of liver in $02(18.1 \%)$ patients \& in right iliac fossa extending into pelvis in $1(9.09 \%)$ patient. In $02(18.1 \%)$ patients multiple Hydatid cysts were noted below left crus of diaphragm near left lobe of liver \& in lesser sac area. Hydatid cysts liver was found in $07(63.6 \%)$ patients. Largest cyst $(10.5 \times 13.0 \mathrm{~cm})$ found in liver while smallest cyst $(3.7 \times 4.0 \mathrm{~cm})$ cyst in epigastric region.

\begin{tabular}{|c|c|c|c|c|c|}
\hline patient & $\begin{array}{l}\text { Extra hepatic Intra- } \\
\text { abdominal Hydatid Cyst }\end{array}$ & $\begin{array}{l}\text { Hepatic } \\
\text { Hydatid } \\
\text { cyst }\end{array}$ & Procedure performed & $\begin{array}{l}\text { Postoperative } \\
\text { Complication }\end{array}$ & $\begin{array}{l}\text { Hospital } \\
\text { Stayl in } \\
\text { days) }\end{array}$ \\
\hline 1 & $\begin{array}{l}\text { In Lesser sac between } \\
\text { stomach, transverse } \\
\text { colon \& Pancreas }\end{array}$ & + & $\begin{array}{l}\text { Complete excision of Extra hepatic } \\
\text { Hydatid cyst \& Saucerization for } \\
\text { Hepatic Hydatid cyst \& omental } \\
\text { packing after removal of cyst } \\
\text { contents }\end{array}$ & Nil & 5.25 \\
\hline 2 & Spleen & - & Splenectomy & $\begin{array}{l}\text { Chest } \\
\text { infection \& } \\
\text { postoperative } \\
\text { gastroparesis }\end{array}$ & 4.70 \\
\hline 3 & $\begin{array}{l}\text { In lesser sac attached to } \\
\text { Pancreas }\end{array}$ & + & $\begin{array}{l}\text { Complete excision of Extra hepatic } \\
\text { Hydatid cyst \& Saucerization for } \\
\text { Hepatic Hydatid cyst \& omental } \\
\text { packing after removal of cyst } \\
\text { contents }\end{array}$ & $\begin{array}{l}\text { Postoperative } \\
\text { pancreatic } \\
\text { fistula }\end{array}$ & 11.25 \\
\hline 4 & $\begin{array}{l}\text { Between left lobe of } \\
\text { Liver, Diaphragm \& } \\
\text { Spleen }\end{array}$ & + & $\begin{array}{l}\text { Complete excision of Extra hepatic } \\
\text { Hydatid cyst \& Saucerization for } \\
\text { Hepatic Hydatid cyst \& omental } \\
\text { packing after removal of cyst } \\
\text { contents }\end{array}$ & Nil & 5.08 \\
\hline 5 & $\begin{array}{l}\text { In Right Iliac fossa } \\
\text { attached to Right Ovary } \\
\text { \& Uterus }\end{array}$ & - & $\begin{array}{l}\text { Complete excision of Hydatid cyst } \\
\text { along with Salpingo-oophorectomy }\end{array}$ & Nil & 2.16 \\
\hline 6 & $\begin{array}{l}\text { Multiple Hydatid Cysts } \\
\text { involving area beneath } \\
\text { left crus of diaphragm \& } \\
\text { lesser sac }\end{array}$ & + & $\begin{array}{l}\text { Complete excision of Extra hepatic } \\
\text { Hydatid cyst \& Saucerization for } \\
\text { Hepatic Hydatid cyst \& omental } \\
\text { packing after removal of cyst } \\
\text { contents }\end{array}$ & $\begin{array}{l}\text { Grade II Wound } \\
\text { infection }\end{array}$ & 6.08 \\
\hline 7 & Spleen & - & Splenectomy & Nil & 3.25 \\
\hline 8 & $\begin{array}{l}\text { In Lesser sac between } \\
\text { stomach, transverse } \\
\text { colon \& Pancreas }\end{array}$ & + & $\begin{array}{l}\text { Complete excision of Extra hepatic } \\
\text { Hydatid cyst \& Saucerization for } \\
\text { Hepatic Hydatid cyst \& omental } \\
\text { packing after removal of cyst } \\
\text { contents }\end{array}$ & Nil & 4.25 \\
\hline 9 & $\begin{array}{l}\text { Between left lobe of } \\
\text { Liver, Diaphragm \& } \\
\text { Spleen }\end{array}$ & + & $\begin{array}{l}\text { Complete excision of Extra hepatic } \\
\text { Hydatid cyst \& Saucerization for } \\
\text { Hepatic Hydatid cyst \& omental } \\
\text { packing after removal of cyst } \\
\text { contents }\end{array}$ & Nil & 6.13 \\
\hline 10 & $\begin{array}{l}\text { In lesser sac attached to } \\
\text { Pancreas }\end{array}$ & + & $\begin{array}{l}\text { Complete excision of Extra hepatic } \\
\text { Hydatid cyst \& Saucerization for } \\
\text { Hepatic Hydatid cyst \& omental } \\
\text { packing after removal of cyst } \\
\text { contents }\end{array}$ & $\begin{array}{l}\text { Postoperative } \\
\text { pancreatic } \\
\text { fistula }\end{array}$ & 13.25 \\
\hline 11 & $\begin{array}{l}\text { Multiple Hydatid Cysts } \\
\text { involving area beneath } \\
\text { left crus of diaphragm \& } \\
\text { lesser sac }\end{array}$ & & $\begin{array}{l}\text { Complete excision of Extra hepatic } \\
\text { Hydatid cyst }\end{array}$ & Nil & 3.50 \\
\hline
\end{tabular}

C.T scan Abdomen performed in 09(81.8\%) patients. It showed hydatid cysts in lesser sac in 04(36.3\%) patients with $02(18.1 \%)$ of them attached to pancreas, below left crus of diaphragm attached to left lobe of liver 
in $02(18.1 \%)$ patients \& in right iliac fossa attached to uterus \& right ovary in $01(9.09 \%)$ patient. Multiple lesions were noted in lesser sac \& in left hypochondrium in $02(18.1 \%)$ patients. Additional lesions found in right lobe of liver in 07 (63.6\%) patients with largest size of $11.0 \times 12.5 \mathrm{~cm}$ in segment $v$ \& viii of right lobe. AntiEchinococcus antibodies were performed in all patients who showed positive result in $08(72.7 \%)$ patients.

Surgery was performed in all patients after 30 days course of Albendazole therapy. Surgical procedures performed include Saucerization \& omental packing after removal of cyst contents from liver for Hepatic Hydatid disease in 07 (63.6\%) patients, Splenectomy in $02(18.1 \%)$ patients, complete excision of intraabdominal extra-hepatic Hydatid cyst in 06(54.5\%) patients. In $02(18.1 \%)$ patients of Hydatid cyst attached to pancreas, these were shaved off from pancreas \& then completely removed. In 01 (9.09\%) patient of Hydatid cyst attached to Right ovary \& right side of Uterus, right Salpingo-oophorectomy was also performed along with complete excision of cyst.

Wound infection \& chest infection was noted in 01 (9.09\%) patient each. $02(18.1 \%)$ patients of Hydatid cyst lesion attached to pancreas developed postoperative pancreatic fistula which was managed conservatively which resolved on $09^{\text {th }} \& 13^{\text {th }}$ postoperative day respectively. $01(9.09 \%)$ patient of hydatid cyst in epigastric region developed postoperative gastroparesis with coffee colored NG aspiration which resolved spontaneously within 05 days. All patients were put on Albendazole therapy for 30 days postoperatively.

\section{DISCUSSION}

Primary peritoneal Hydatid cyst is a very rare disease and mostly it is secondary in origin with primary site being the Liver. Pedrosa $\mathrm{I}$ et $\mathrm{al}^{10}$ in their study at Department of Diagnostic Imaging Madrid, Spain found peritoneal Hydatid disease in approximately $13 \%$ of patients. In their study cause of such high frequency was related to previous surgery for hepatic Hydatid disease. However, spontaneous rupture of hepatic Hydatid cysts leading to peritoneal Hydatid disease was also found commonly in this group of patients.

In study on 34 patients of Primary and isolated extrahepatic intra-abdominal hydatid cysts by Makni A et al $^{11}$ at Al-Rabta Hospital Tunisia, mean age was 46 years. Among the symptoms Abdominal pain was the commonest symptom noticed in 27 patients (79.4\%) while examination findings showed Mass in abdomen in 19 patients $(55.9 \%)$. Balik AA et al ${ }^{12}$ in their study of 19 years on surgically treated cases of extra hepatic abdominal hydatid disease at Ataturk
University Erzurum, Turkey found associated hepatic hydatid cysts in 19 patients while primary peritoneal hydatid cysts were found in 8 patients. These cysts were located in the spleen, pancreas, adrenal gland, mesentery of the intestine, ovaries, retroperitoneum, omentum, abdominal wall, rectovesical region, and the psoas muscle. Beyrouti $\mathrm{Ml}$ et $\mathrm{al}^{13}$ in their study of 11 years found 970 patients who underwent surgery for hydatid cysts of the liver and the spleen. Amongst them $17(1.75 \%)$ patients presented as acute rupture of the hydatid cyst into the peritoneal cavity. Trauma was responsible for acute rupture in 6 cases and strenuous physical activity in 1 case. 14 cases presented as acute peritonitis, 1 case as acute intestinal occlusion. While suggested anaphylactic shock \& non-complicated hydatid cyst were found in 1 patient each ${ }^{13}$.

Clinical diagnosis of Peritoneal Hydatid disease is challenging and may be made when cysts are large enough to produce symptoms as palpable mass or compression symptoms on surrounding viscera's $\mathrm{s}^{7,14,15}$.

Diagnosis of hydatid disease is usually made on ultrasound report and serologic tests by ELISA or haemagglutination methods ${ }^{16}$. CT scan is superior to ultrasound in determining the number, size and location of the intrahepatic \& extra hepatic Hydatid cysts. Surgery renders the definitive diagnosis of hydatid cysts ${ }^{17}$.

In study by Beyrouti $\mathrm{Ml}$ et $\mathrm{al}^{13}$ Ultrasound abdomen was able to make the diagnosis of hydatid disease of liver in all 17 cases, but diagnosis of peritoneal Hydatid disease was made cavity in 12 cases only. CT scan Abdomen was not performed in any patient ${ }^{13}$.

Makni A \& colleagues ${ }^{11}$ noticed significant difficulties in making the diagnosis of pancreatic hydatid cyst, even with modern imaging techniques. In their study $25(73.5 \%)$ patients underwent conservative surgery with $3(8.8 \%)$ of them developed recurrence which were reoperated. Complete surgical excision, when possible without major sacrifice, seems to be the best therapeutic option to reduce the risk of recurrence.

Balik AA et al $^{12}$ removed viscera's in 8 patients due to organ destruction by large cysts. Pericystectomy was performed in 19 patients. Postoperative mortality or severe morbidity was not found in their study. They used antihelminth drugs in patients having peritoneal spillage.

In their study by Beyrouti MI \& collaeges ${ }^{13}$ surgery was performed in 16 patients with peritonitis due to ruptured hydatid cyst from hydatid cysts in the liver and spleen. Post-operative follow-up was complicated in 4 cases with two deaths through septic shock. In their study 06 
patients were put on with Albendazole treatment with 01 patient of them developed dissemination of hydatid disease into the peritoneum.

Gollackner B \& colleagues $^{18}$ put 37 patients $(50 \%$ ) on perioperative antihelmintic chemotherapy with Mebendazole (18 patients) or Albendazole (19 patients). They noted morbidity in $25 \%$ patients treated with conservative surgery and in $24.1 \%$ with radical surgery. Mortality was $5 \%$ with conservative surgery and $1.8 \%$ with radical surgery. 32 patients tolerated antihelmintic therapy well. Sixty $(81.0 \%)$ patients attended followup clinics with median period of 7.2 years \& range $2.0-$ 47.0 years. Recurrent hydatid disease was noted in 9 patients during the period 3 months to 20 years which was significantly lower after radical surgical procedures $(p=0.03)$ and after complete removal of the cyst $(p=$ $0.04)^{18}$.
Michael OP \& collaegues ${ }^{19}$ treated a patient of recurrent retro rectal pelvic hydatid cyst with three courses of Albendazole. Sixteen weeks later review CT scan performed before planned surgical procedure showed disappearance of the cyst with a decrease in the $\lg G$ anti-echinococcal antibody titers to lower level.

\section{CONCLUSIONS}

Extra hepatic intra-abdominal is an infrequent disease presents significant diagnostic \& therapeutic challenge for surgeons. It should be included in the differential diagnosis of mass Abdomen. Most commonly it is secondary in origin with primary site is usually Liver. Every effort should be made to avoid spillage of contents during surgery to prevent recurrence of disease.

\section{ACKNOWLEDGMENTS}

To my patients who participated in this study

\section{REFERENCES}

1. Serhal S, Sebai F, Mestiri S. Hydatid cyst of the pancreas. Apropos of 3 cases. J Chir-Paris. 1987; 24:542-4. PMID:3320069

2. Özdemir N., Akal M., Kutlay H., Yavuzer $\square$. Chest wall echinoccocosis. Chest, 1994, 105: 1277-9. PMID: 8162770

3. Hatipog Lua R, Coskun I, Karakaya K, Ibis C. Retroperitoneal localization of hydatid cyst disease. Hepato-Gastroenterol, 2001, 48: 1037-9. PMID:11490794

4. Rodriguez Vargas J, Arroyo Carrera I, Pitarch Esteve V. Pancreatic hydatid cysts. Chir Pediatr. 1992; 5:46-7. PMID:1567748

5. Khiari A, Mzali R, Ouali M, Kharrat M, Kechaou MS, Beyrouti MI. Hydatid cyst of the Pancreas. Apropos of 7 cases. Ann Gastroent Hepato (Paris). 1994; 30:87-91. PMID:8067682

6. Bansal VK, Misra MC, Krishna A, Kumar S, Garg P, Khan RN, Loli A, Jindal V. Pancreatic hydatid cyst masquerading as cystic neoplasm of Pancreas, A case Report. Trop Gastroenterol 2010 Oct - Dec; 31(4): 335 - 7. PMID: 21568157

7. Elton C, Lewis M, Jourdan M.H. Unusual site of hydatid disease. Lancet, 1999, Jun 17; 355(9221):2132. PMID: 10902628

8. Z.Türkyılmaz, K. Sönmez, R. Karabulut, Í. H. Göl, A. C. $\mathrm{Ba} \square$ aklar, N. Kale. Unusual Localization of Hydatid Cyst. Acta Chir Belg, 2006 Jul-Aug; 106(4):443-4. PMID: 17017705

9. Bedioui H, Ayari H, Bouslama K, Maghrebi H, Hsairi H, Jouini M, Kacern M, Safta JM, Ben Z. Recurrence of hydatid cyst of liver: predictive Factors: Tunisian experience]. B Soc Pathol Exot. 2012 Oct; 105(4):265-9. doi: 10.1007/ s13149-012-0243-z. Epub 2012 Sep 7. PMID: 22961646

10. Pedrosa I, Saiz A, Arrazola J, Ferreiros J, Pedrosa CS. Hydatid disease: radiologic and pathologic features and complications. Radiographics. 2000 May-Jun; 20(3):795-817. PMID:10835129
11. Makni A, Jouini M, Kacem M, Safta ZB. Extra-hepatic intra-Abdominal hydatid cyst: Which characteristic, compared to the hepatic Location? Updates Surg. 2013 Mar; 65(1):25-33. doi: 10.1007/s13304-012-0188-6. Epub 2012 Dec 5. PMID:23212183

12. Baliki I.A.A, Çelebi F., Basog ${ }^{\complement} \mathrm{Lu}$ M, Ören D, Yildirgan I, AtamanalpS.S. Intra-Abdominalextrahepaticechinoccocosis. Surg Today, 2001;31(10):881-4. PMID:11759882

13. Beyrouti $\mathrm{MI}^{1}$, Beyrouti R, Abbes I, Kharrat M, Ben Amar M, Frikha F, Elleuch S, Gharbi W, Chaabouni M, Ghorbel A. Acute rupture of hydatid cysts in the peritoneum: 17 cases. Presse Med.2004 Mar 27; 33(6):378-84. PMID:15105779

14. Kern P, Bardonnet K, Renner E, Auer H, Pawlowski Z, Ammann RW, Vuitton DA, Kern P, European Echinococcosis Registry: human alveolar echinoccocosis. Emerg Infect Dis 2003 Mar; 9(3):343-9. PMID:12643830; PMCID: PMC2958541

15. Morar R, Feldman C. Pulmonary echinoccocosis. Eur Respir J. 2003 Jun;21(6):1069-77. PMID:12797504

16. Kalinowska NA, Begejowicz C. Current principles for diagnosis and treatment of Hydatid disease. Przegl. Lek. 2001; 58(3):143-6. PMID:11475862

17. Kervancioglu R, Bayram M, Elbeyli L. CT findings in pulmonary hydatid disease. Acta Radiol 1999 Sep; 40(5):510-4. PMID: 10485240

18. Gollackner B, Längle F, Auer H, Maier A, Mittlböck M, Agstner I, Karner J, Langer F, Aspöck H, Loidolt H, Rockenschaub S, Steininger R. Radical Surgical Therapy of Abdominal Cystic Hydatid Disease: Factors of Recurrence. World J Surg. June 2000 Jun; 24(6):717-21. PMID:10773125

19. Michail OP, Georgiou C, Michail PO, Felekouras E, Karavokyros I, Marinos G, Giannopoulos A, Griniatsos J. Disappearance of recurrent intra-abdominal extra hepatic hydatid cyst following oral Albendazole administration. W Indian Med J. 2007 Sep; 56(4):372-5. PMID:18198745 